\title{
Critical variables in the profile of the seller of new vehicles in the Toluca Valley
}

\section{Variables críticas en el Perfil del vendedor de vehículos nuevos en el Valle de Toluca}

\author{
OLVERA-ESPINOSA, Edgar $\dagger$, PEDRONI-LARA, Fernando, VILLASEÑOR-PADILLA, Dania Elba \\ and ALMEYDA-VILLAVICENCIO, Eduardo
}

Universidad Tecnológica del Valle de Toluca, Mexico.

ID $1^{\text {st }}$ Author: Edgar, Olvera-Espinosa / ORC ID: 0000-0001-8872-6575, CVU CONACYT ID: 240003

ID $1^{\text {st }}$ Co-author: Fernando, Pedroni-Lara / ORC ID: 0000-0002-9194-4079

ID $2^{\text {nd }}$ Co-author: Dania Elba, Villaseñor-Padilla / ORC ID: 0000-0002-3003-061X

ID $3^{\text {rd }}$ Co-author: Eduardo, Almeyda-Villavicencio

DOI: $10.35429 / J I E C .2020 .7 .4 .28 .38$

Received July 25, 2020; Accepted December 30, 2020

\begin{abstract}
One of the industries that contribute a greater proportion to the GDP in Mexico is the automotive industry, which is why it is one of the engines of the National economy. Given the diversity of brands that compete in the market, differentiation is a very important element, however it is necessary to adapt to consumer preferences and know how to communicate it. In this sense, the sales staff of the automotive marketer is responsible for identifying the needs of the potential customer and convincing him about the purchase. The objective of this research is to analyze the seller's profile using the MORACH feedback model, to identify the critical variables for successful sales, as well as the areas of opportunity for the sales force. It is analyzed by applying the MORACH model and the $360^{\circ}$ Assessment. The main contribution is to provide the identification of critical factors in times of crisis, such as that caused by COVID-19.
\end{abstract}

Seller profile, Performance evaluation, COVID-19 automotive crisis

\begin{abstract}
Resumen
Una de las industrias que aportan en mayor proporción al PIB en México es la automotriz, por lo cual es uno de los motores de la economía Nacional. Ante la diversidad de marcas que compiten en el mercado, la diferenciación es un elemento muy importante, sin embargo, es necesario adaptarse a las preferencias de los consumidores y saber comunicarlo. En este sentido, el personal de ventas de la comercializadora automotriz es el responsable de identificar las necesidades del posible cliente $\mathrm{y}$ convencerlo acerca de la compra. Esta investigación tiene por objetivo analizar el perfil del vendedor mediante el modelo de retroalimentación MORACH, para identificar las variables críticas para la venta exitosa, así como las áreas de oportunidad de la fuerza de ventas. Se analiza mediante la aplicación del modelo MORACH y la Evaluación $360^{\circ}$. La principal contribución, es proporcionar la identificación d ellos factores críticos en tiempo de crisis, como la ocasionada por el COVID-19.
\end{abstract}

Perfil del vendedor, Evaluación del desempeño, Crisis automotriz COVID-19

Citation: OLVERA-ESPINOSA, Edgar, PEDRONI-LARA, Fernando, VILLASEÑOR-PADILLA, Dania Elba and ALMEYDA-VILLAVICENCIO, Eduardo. Critical variables in the profile of the seller of new vehicles in the Toluca Valley. RINOE Journal - International Economy. 2020. 4-7:28-38.

$\dagger$ Researcher contributing first author. 


\section{Introduction}

During 2020, the automotive industry in Mexico contributed $3.8 \%$ of the national GDP and $20.5 \%$ of the manufacturing GDP, the second economic activity with the highest contribution to the manufacturing GDP, despite having stopped activities during April and May 2020 (INFOAB, 2020). Although in 2018 it generated 1.9 million jobs, of which 516 thousand belong to the automotive trade segment (AMIA, 2018), in 2019 it went from 867,000 to 812,000 job sources compared to the same period in 2019 (González, El Economista, 2020). With around 37 brands participating in the market, it is very important to differentiate yourself from the competition.

Although there are digital consultation tools that provide information to potential buyers, the role of the seller is decisive in the automotive sales process. Although various authors have proposed types of sellers, it is important to identify the competencies required in the seller's profile that add value to the organization and that allow identifying the qualities of the person to define their profile, against the one required by the organization and that it can be of any profession and is trained in sales throughout his career in the area and develops skills from experience.

In this research, a $360^{\circ}$ evaluation was applied to 38 sellers of an automotive distribution group in the Toluca Valley in 3 of its automotive agencies, using the MORACH model, to identify the relational competencies of each seller, which in summary are valued using the variables Carol Ryff's well-being model, where the degree of development is measured in the variables: Environmental control, Personal growth, Purpose in life, Autonomy, Selfacceptance and Positive relationships with others.

On the other hand, the psychodynamics of the salesperson, the correlation between variables, and those that are critical based on the profile were identified. The information obtained allowed us to identify the areas of opportunity of the sales team, as well as, about training, the development of the members and their performance.

\section{Theoretical framework}

Economic context of the industry

Today Mexico has presented a series of situations and challenges in an uncertain world context full of uncertainty, where a $6 \%$ drop in employment in the industry is anticipated (González, El Economista, 2020). On the other hand, analysts believe that in the coming months they will mark the economic rhythm towards a global slowdown, but not a recession, however the trends of the three largest economies, from the world a panorama of less growth dynamics is observed in the next three quarters.

With the foregoing, it can be seen that in Mexico the automotive industry advances in its investments with caution for the Mexican domestic market, also coupled with the different events of public policies that will mark in the short and medium term, the performance of economic growth and the Automotive industry. However, in the Mexican domestic market in terms of sales there has been a $9.7 \%$ reduction in the purchase of new cars through credit between January and May 2019 compared to the same period in 2018 according to the Mexican Association of Automotive Distributors (AMDA), and for the fourth quarter of 2020 a $28 \%$ drop is expected (Martínez, 2020). According to Guillermo Rosales, Director of the AMDA, financing sales went from $70.2 \%$ in the first five months of 2018 to $68.1 \%$ in 2019 and for the first half of 2020 it was $62.1 \%$, which shows that the strength of credit is losing automotive, which has a notable impact on total sales of $6.4 \%$ decrease in the first semester and 25 consecutive months of falls (González, El Economista, 2019). Therefore, the slowdown in the Mexican economy is notable, since it must be remembered that both the automotive industry, as well as the construction, textile, food industries, among others, are the locomotives of economic growth in Mexico.

\section{Labor Competencies}

The concept of "labor competition" has become more relevant in the corporate world; emerges as a frame of reference for the administration and development of personnel in corporations". 
"They are the set of knowledge and professional qualities necessary for an employee to successfully perform a set of functions or tasks, and by extension the set of knowledge and qualities necessary to successfully develop the business of an organization; their behaviors that some people master better than others, and that makes them more effective in a given situation". (Noyola, 2011, p. 86)

\section{Seller psychodynamics}

From the perspective of psychology, as a science that studies the interactions between people and the environment, it seeks to define laws that govern the processes in order to establish improvements between human beings and the way of relating in the future. The psychodynamics of the seller refers to the interaction between prospects and sellers, the techniques applied during the sales process and the effects obtained from them, identifying the positive effects to apply them in subsequent operations, in such a way that it leads to prospect to make the purchase (Llamas, 2009).

\section{Definitions}

Psychology. Discipline that aims to analyze the mental and behavioral processes of human beings and their interactions with the physical and social environment. Therefore, psychology means study or treatise on the psyche.

Psyche is the set of human capacities of an individual that encompasses conscious and unconscious processes (Llamas, 2009).

Psychodynamics. F. Term used by some schools to refer to the functioning of the psyche.

Psychism. m. Set of psychological functions and processes (perception, thought, memory, emotion, motivation, etc.) that constitute the "mental" activity of a person. This term is used as a synonym for mind to avoid the metaphysical connotations that usually accompany the latter (Llamas, 2009).

From this, it is possible to identify six approaches to the seller's action (Llamas, 2009):
1. That of the seller oriented to satisfy his own problems: his main concern is to satisfy himself and his problems, he strives to meet the goal of the month, his goal is to make money, he is not interested in the problems of prospects.

2. The salesperson oriented towards the competition: his objective is to annihilate the competition; his arguments are focused on minimizing the competitors rather than on satisfying the needs of his prospect.

3. The salesperson oriented only towards his product: He knows the argument very well, he closes his mind to the other products, he ignores the knowledge, suggestions, interests, wishes and conveniences of the prospect. He likes to hear himself.

4. The salesman oriented to bargains: He talks about special offers, promotional campaigns, he is not interested in the fundamental but the accessory, he leaves aside scientific advances, for a special offer, for him, the product is not worth what it is but for how much less it costs.

5. The salesperson oriented only towards relationships: $\mathrm{He}$ is interested in winning the friendship of the prospect, he acts as a public relationsist, he focuses so much on the prospect that he talks about all kinds of topics, leaving aside the qualities of the product or service, to finally ask about need and attempt to place an order.

6. The technical salesperson: His concern is to guide, advise and serve, he cares about knowing the problems and motivations of the prospect, knows his product well, talks about the benefits and knows how to adapt the qualities to the prospect, uses a technical and persuasive process to demonstrate what the product or service can do for him.

\section{Selling based on trust}

Based on the psychodynamics of the salesperson, although the relationship-oriented salesperson has a special ability to develop friendly relationships, trust is considered to be an element that must be evaluated and fostered. 
Selling based on trust, is a form of personal selling, it requires the seller to generate trust in customers and that they apply a sales strategy that meets their needs and contributes to creating, communicating and providing value, focuses on solving problems of customers, provide opportunities and long-term value. It involves a high degree of listening. Confidence in the seller is the degree of integrity that the buyer perceives in the seller, the ability of the seller to sustain his statements, promises and that the entire company will support him (Ingram, LaForge, Ávila, \& Schwepcker, 2016).

\section{Soft Skills}

To address the seller's profile in relation to psychodynamics, some transversal competences are considered, considered as soft, which, although not properly considered, provide a context, the study is:

- Empathy: Put yourself in the shoes of others and have solidarity with others.

- Sociability: Create contact networks over time and not be just "one more" at work.

- Improve your communication skills: Be able to communicate your ideas, opinions, concerns and even complaints.

- $\quad$ Knowing how to listen: Listening carefully to others and paying them $100 \%$ attention will make them perceive you as a person of value.

- Teamwork: Although many people are not fans of teamwork and many times it can, in fact, mean less production on a specific task, it is essential to:

- Be creative: It is better to propose many ideas, regardless of whether they come to fruition or not, than to remain silent.

- Solve problems: Having the ability to deal with them, find simple and direct solutions and not collapse is one of the habits that you have to start putting into practice.

- $\quad$ Assertiveness: Do not show doubts in your opinions or proposals.
- Pressure tolerance: Having the ability to withstand stressful and high-pressure situations.

- Be responsible: Being punctual with schedules, meeting the promised times and responding to the demands of your position is essential for your work success.

- Adaptation to change: Avoid entering a comfort zone. Situations within the company or organization will always change.

- $\quad$ Positive attitude: Focusing on maintaining a positive vision of what your job means, of how you got there and of the many people who would like to be in your current position, you will not get stuck in negative thoughts that will not help you achieve your goals.

- $\quad$ Spirit of service: Have the ability to want to help without necessarily having to receive anything in return.

- $\quad$ Respect the opinions of others. Even if you think they are totally wrong.

- Be proactive: Don't wait for them to tell you that you have to do a certain task to do it.

- Be persistent. Getting frustrated and giving up is very easy. It is important not to waste time on tasks that are not progressing, but at the same time, it is essential to be persistent and not give up. You have to be constant in the tasks that you propose to carry out, not only in your work life. Reaching your goals will depend on the discipline and perseverance you have. (cursando.com, 2019).

For the $360^{\circ}$ evaluation, the MORACH model was chosen, which follows the following steps: 


\section{9}

\section{Figure 1}

Source: (Olvera, Pedroni, \& Pérez, Organizational Feedback Model for Human Capital Learning: MORACH, 2017)

The variables that were considered for this research are related to those known as soft skills, although different opinions on the part of different authors the socio-emotional variables that were considered are: Environmental control, personal growth, purpose in life, autonomy, selfacceptance and positive relationships with others. To understand them, the following table is presented:

\begin{tabular}{|c|c|c|}
\hline Dimension & Optimum level & Deficit level \\
\hline $\begin{array}{l}\text { Environmental } \\
\text { control }\end{array}$ & $\begin{array}{l}\text { Feeling of } \\
\text { control and } \\
\text { competence, } \\
\text { control of } \\
\text { activities, take } \\
\text { advantage of } \\
\text { opportunities, } \\
\text { able to create or } \\
\text { choose contexts }\end{array}$ & $\begin{array}{l}\text { Feelings of } \\
\text { helplessness, } \\
\text { generalized } \\
\text { external locus, } \\
\text { feeling out of } \\
\text { control }\end{array}$ \\
\hline $\begin{array}{l}\text { Personal } \\
\text { growth }\end{array}$ & $\begin{array}{l}\text { Feeling of } \\
\text { continuous } \\
\text { development, } \\
\text { sees himself in } \\
\text { progress, open to } \\
\text { new experiences, } \\
\text { able to appreciate } \\
\text { personal } \\
\text { improvements }\end{array}$ & $\begin{array}{l}\text { Feeling of not } \\
\text { learning, feeling } \\
\text { of not } \\
\text { improving, not } \\
\text { transferring past } \\
\text { or present } \\
\text { achievements }\end{array}$ \\
\hline Purpose in life & $\begin{array}{l}\text { Goals in life, a } \\
\text { feeling of being } \\
\text { on track, a } \\
\text { feeling that the } \\
\text { past and the } \\
\text { present have } \\
\text { meaning. }\end{array}$ & $\begin{array}{l}\text { A sense of being } \\
\text { aimless, } \\
\text { psychosocial } \\
\text { difficulties, low } \\
\text { premorbid } \\
\text { functioning. }\end{array}$ \\
\hline
\end{tabular}

\begin{tabular}{|c|c|c|}
\hline Dimension & Optimum level & Deficit level \\
\hline Autonomy & $\begin{array}{l}\text { Able to resist } \\
\text { social pressure, } \\
\text { he is independent } \\
\text { and determined, } \\
\text { regulates his } \\
\text { behavior from } \\
\text { within, and } \\
\text { evaluates } \\
\text { himself. }\end{array}$ & $\begin{array}{l}\text { Low level of } \\
\text { assertiveness, } \\
\text { not showing } \\
\text { preferences, } \\
\text { submissive and } \\
\text { complacent } \\
\text { attitude, } \\
\text { indecision. }\end{array}$ \\
\hline $\begin{array}{l}\text { Self } \\
\text { acceptance }\end{array}$ & $\begin{array}{l}\text { Positive attitude } \\
\text { towards oneself, } \\
\text { accepts positive } \\
\text { and negative } \\
\text { aspects, } \\
\text { positively values } \\
\text { his past. }\end{array}$ & $\begin{array}{l}\text { Perfectionism, } \\
\text { more use of } \\
\text { external criteria. }\end{array}$ \\
\hline $\begin{array}{l}\text { Positive } \\
\text { relationships } \\
\text { with others }\end{array}$ & $\begin{array}{l}\text { Close and warm } \\
\text { relationships } \\
\text { with others, he is } \\
\text { concerned about } \\
\text { the welfare of } \\
\text { others, capable of } \\
\text { strong empathy, } \\
\text { affection and } \\
\text { intimacy. }\end{array}$ & $\begin{array}{l}\text { Deficits in } \\
\text { affection, } \\
\text { intimacy and } \\
\text { empathy. }\end{array}$ \\
\hline
\end{tabular}

Table 1

Source: (Hervás, 2009)

To evaluate them, the Organizational Model of Feedback for the Learning of Human Capital: MORACH (Olvera, Pedroni, \& Pérez, Organizational Model of Feedback for the Learning of Human Capital: MORACH, 2017), considers the subvariables:

\begin{tabular}{|c|c|}
\hline Dimensions of well-being & $\begin{array}{l}\text { Performance } \\
\text { variable }\end{array}$ \\
\hline \multirow{4}{*}{$\begin{array}{l}\text { Positive relationships with } \\
\text { others }\end{array}$} & Teamwork \\
\hline & Availability \\
\hline & Sociability \\
\hline & Collaboration \\
\hline \multirow[t]{4}{*}{ Autonomy } & Puntuality \\
\hline & Responsibility \\
\hline & Patience \\
\hline & Creativity \\
\hline \multirow[t]{3}{*}{ Environmental control } & Assertiveness \\
\hline & Performance \\
\hline & Self-control \\
\hline \multirow[t]{3}{*}{ Self acceptance } & Leadership \\
\hline & Influence \\
\hline & Self-confidence \\
\hline \multirow[t]{4}{*}{ Personal growth } & Reliability \\
\hline & Loyalty \\
\hline & Honesty \\
\hline & Integrity \\
\hline \multirow[t]{4}{*}{ Purpose in life } & Commitment \\
\hline & Initiative \\
\hline & Honesty \\
\hline & Solidarity \\
\hline
\end{tabular}

Table 2 Control of variables

Source: (Olvera, Analysis of performance evaluation, 2016)

OLVERA-ESPINOSA, Edgar, PEDRONI-LARA, Fernando, VILLASEÑOR-PADILLA, Dania Elba and ALMEYDAVILLAVICENCIO, Eduardo. Critical variables in the profile of the seller of new vehicles in the Toluca Valley. RINOE Journal International Economy. 2020 
The MORACH instrument that is applied includes 92 statements that are assessed on a scale: 1 Unsatisfactory; 2 Minimum required for the position; 3 In the standard; 4 Good / above standard; 5 Much Above Standard:

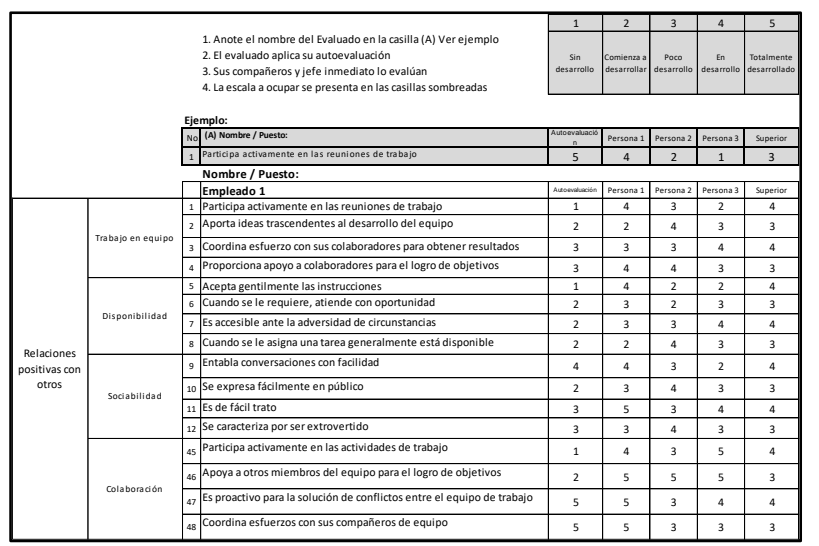

Table 3 Sample of instrument section

Source: (Olvera, Analysis of performance evaluation, 2016)

According to the model, averages are calculated per variable, standard deviation and the coefficient of variation, derived from which it is possible to identify the three where there is the greatest coefficient of variation are the weaknesses and those with the least variation are the strengths of the person.

\begin{tabular}{|l|r|r|r|r|r|r|}
\hline Empleado 1 & P. A. & P.C. & P.s. & P.P. & DV & cV \\
\hline Trabajo en equipo & 2.3 & 3.3 & 3.5 & 3.0 & 0.7 & 4.5 \\
\hline Disponibilidad & 1.8 & 2.9 & 3.5 & 2.7 & 0.9 & 3.1 \\
\hline Sociabilidad & 3.0 & 3.4 & 3.5 & 3.3 & 0.3 & 12.3 \\
\hline Colaboración & 3.3 & 4.2 & 3.5 & 3.6 & 0.5 & 7.7 \\
\hline Puntualidad & 2.3 & 3.4 & 3.5 & 3.1 & 0.7 & 4.4 \\
\hline Responsabilidad & 2.3 & 3.9 & 3.5 & 3.2 & 0.9 & 3.7 \\
\hline Paciencia & 2.3 & 4.0 & 3.8 & 3.3 & 0.9 & 3.5 \\
\hline Creatividad & 2.3 & 3.3 & 3.5 & 3.0 & 0.7 & 4.5 \\
\hline Asertividad & 3.0 & 4.0 & 3.5 & 3.5 & 0.5 & 7.0 \\
\hline Desempeño & 2.3 & 4.2 & 3.5 & 3.3 & 1.0 & 3.4 \\
\hline Autodominio & 2.3 & 3.5 & 3.5 & 3.1 & 0.7 & 4.3 \\
\hline
\end{tabular}

Table 4 Sample of the results table

Source: (Olvera, Analysis of the performance evaluation, 2016)

The MORACH determines that the weaknesses or areas of opportunity are sociability, collaboration and assertiveness; and strengths: availability, performance, and patience (Olvera, Pedroni, \& Pérez, Organizational Feedback Model for Human Capital Learning: MORACH, 2017). Since this is how the seller is perceived.
Subsequently, for the interpretation of the data regarding the welfare variables, the same process is carried out, reducing to two areas of opportunity and two strengths.

\begin{tabular}{|l|r|r|r|}
\multicolumn{1}{|c}{ Variable } & \multicolumn{1}{c}{$\boldsymbol{\mu}$} & \multicolumn{1}{c}{ DV } & \multicolumn{1}{c|}{ CV } \\
\hline $\begin{array}{l}\text { Positive } \\
\text { relationships with } \\
\text { others }\end{array}$ & 3.2 & 0.6 & 6.9 \\
\hline Autonomy & 3.2 & 0.8 & 4.0 \\
\hline $\begin{array}{l}\text { Environmental } \\
\text { control }\end{array}$ & 3.3 & 0.7 & 4.9 \\
\hline Self-acceptance & 3.0 & 0.7 & 4.0 \\
\hline Personal growth & 3.1 & 0.7 & 4.3 \\
\hline Purpose in life & 3.1 & 0.7 & 4.3 \\
\hline
\end{tabular}

Table 5 Results of performance measurement in the area of well-being

Source: (Olvera, Analysis of performance evaluation, 2016)

Additionally, graphs are made for a better visual understanding.

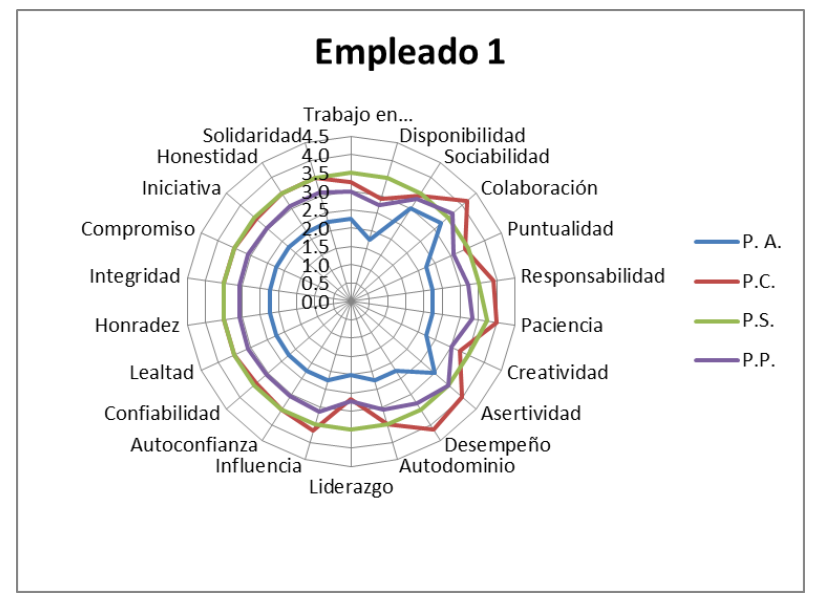

Graphic 1 Performance results

Source: (Olvera, Performance evaluation analysis, 2016)

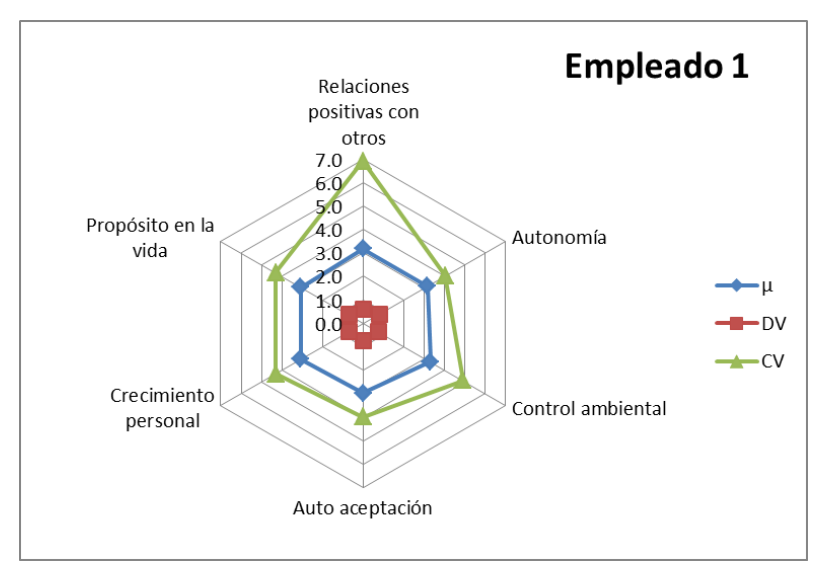

Graphic 2 Wellness performance results

Source: (Olvera, Performance evaluation analysis, 2016) 
From the results it is possible to take specific actions and determine areas of development; How it is possible to appreciate in graphs 2 and 3 there is a relationship in terms of sociability, assertiveness and collaboration based on positive relationships with others and environmental control.

According to the model, it is possible to appreciate that the highest coefficient of variation occurs in personal growth and positive relationships with others; while the lowest coefficient of variation, which can be considered strength, is autonomy and self-acceptance. The application of this evaluation allows obtaining sufficient data to calculate the correlation coefficient between the variables, so that in a matrix the correlation coefficient is calculated, where the values closest to 1.0 are those with the highest correlation and the furthest are those with less or no correlation. As can be seen in Table 7 , the variables can influence a leverage for the greater development of the person. Values greater than 0.999 were established as a greater correlation. (Olvera, Pedroni, \& Pérez, Organizational Feedback Model for Human Capital Learning: MORACH, 2017)

\section{Methodology to be developed}

\section{Objectives}

Identify the critical variables of the seller's profile through the $360^{\circ} \mathrm{MORACH}$ evaluation model, to select those that require development in the sales team.

\section{Materials and methods}

To apply the MORACH, the first thing was to expose the project to the managers to obtain authorization from the general managers and collaborate with the sales managers, in order to dedicate as little time as possible.

To apply the instrument, a Google $®$ form was used and an application schedule was made, since the time spent per salesperson was around 35 minutes, since they had to self-evaluate and evaluate their colleagues. In the case of sales managers, they evaluated each of the salespeople on their work team, which delayed the data collection work for two weeks. Due to the length of the study, four scholarship holders were trained in order to answer questions and explain some terms.
The data were concentrated by means of Microsoft ${ }^{\circledR}$ Excel and averages, standard deviation, coefficient of variation and correlation coefficient were calculated. Tables and radial graphs were made to achieve a better appreciation of the data.

\section{Results}

It manages to appreciate variables in which it can be said that there is a high correlation, identified with a one, for example: Teamwork with contact modalities and with responsibility.

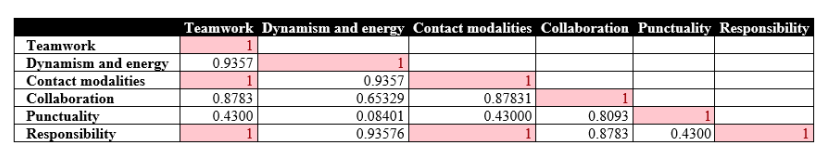

Table 6 A vendor correlation table fragment

By calculating the averages, it was possible to identify the variables that have the highest incidence for each seller, so that specific results are obtained that are very useful for the person, identifying strengths and weaknesses that at the time of feedback, they discover their self-perception by themselves. and how it is perceived, aspects that affect its interaction with the client.

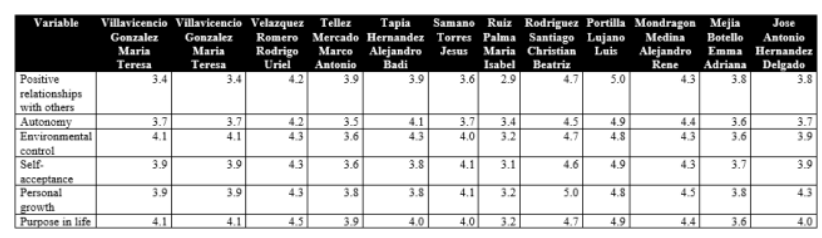

Table 7 Results by variable of each seller Source: (Own elaboration)

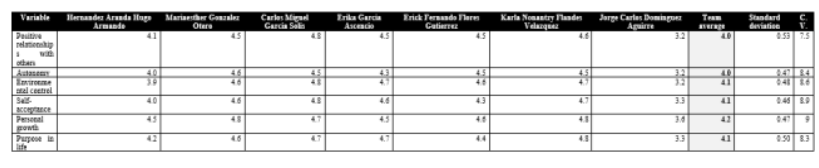

Table 8 Continuation of results by variable of each seller Source: (Own elaboration)

When observing the average, it is possible to appreciate that positive relationships with others: (Close and warm relationships with others, concerned about the well-being of others, capable of strong empathy, affection and intimacy) is one of those that obtained the lowest score.

When analyzing the standard deviation of each variable in the work team, from the perspective of the 6 well-being variables, a radial Graphic was obtained in which the areas of opportunity are clearly appreciated.

OLVERA-ESPINOSA, Edgar, PEDRONI-LARA, Fernando, VILLASEÑOR-PADILLA, Dania Elba and ALMEYDAVILLAVICENCIO, Eduardo. Critical variables in the profile of the seller of new vehicles in the Toluca Valley. RINOE Journal International Economy. 2020 


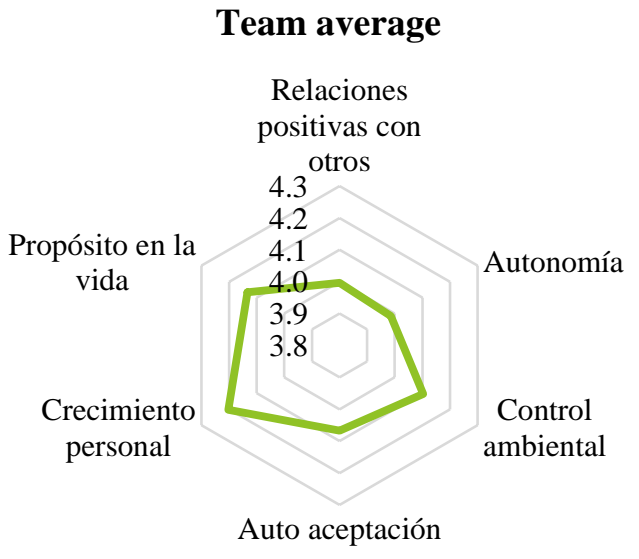

Graphic 3 Critical variables of well-being Source: (Own elaboration)

According to the psychodynamics of the seller, it is observed that the average of the sellers is oriented to satisfy their own problems, for which it is necessary to strengthen, by virtue of the seller fulfilling his personal objectives, aligning them with the objectives of his position, such as sales, customer prospecting, portfolio recovery, among other responsibilities.

The critical variables that were identified in the seller's profile are negatively affected, since:

1. Environmental control: The seller has some difficulty feeling competent and creating new contexts to prospect, although he has skills for time control and organization.

2. Personal growth: Feeling of continuous development, sees himself in progress, open to new experiences, able to appreciate personal improvements, although it can negatively affect the client, since it denotes a personal interest.

3. Purpose in life: Setting goals in life, the feeling of being on track, feeling that the past and the present have a meaningful direction, can be affected by motivation as a result of the venat or demotivation in the absence of sales.

4. Autonomy: Deficit in the ability to resist social pressures, is not very independent and requires greater determination, difficulties in regulating their behavior from within, and difficulty in selfevaluation.
5. Self-acceptance: It requires improving the positive attitude towards oneself, accepts aspects more negative than positive aspects, may have conflicts to positively value their past.

6. Positive relationships with others: Have difficulty developing close and warm relationships with others, is more concerned with personal well-being than that of others, difficulty in developing empathy, affection and intimacy.

The area with the highest score on average was personal growth, so the mobile is primarily personal, since the usual salary scheme is low commission and when meeting personal goals it adds up to the organization, on the other hand the variable of Positive Relationships with others it is the least, which requires strengthening, since the sales function itself depends on the relationships that are developed with people, a situation that can impact the process of prospecting, closing the sale and even after-sales.

It is important to consider that the client goes to see vehicles of a certain brand based on their experience, available information, advertising, recommendations from relatives and acquaintances, in such a way that they go with a certain predisposition, it is determined that the best seller profile requires a technical and environmental control approach and the seller must be prepared.

When reviewing the individual correlation tables, when viewing the detail, correlation between certain variables is appreciated, however, in the summary of the six variables, the correlation is not appreciated.

The Standard Deviation Graphic shows the areas of opportunity, in this case Positive relationships with others. 


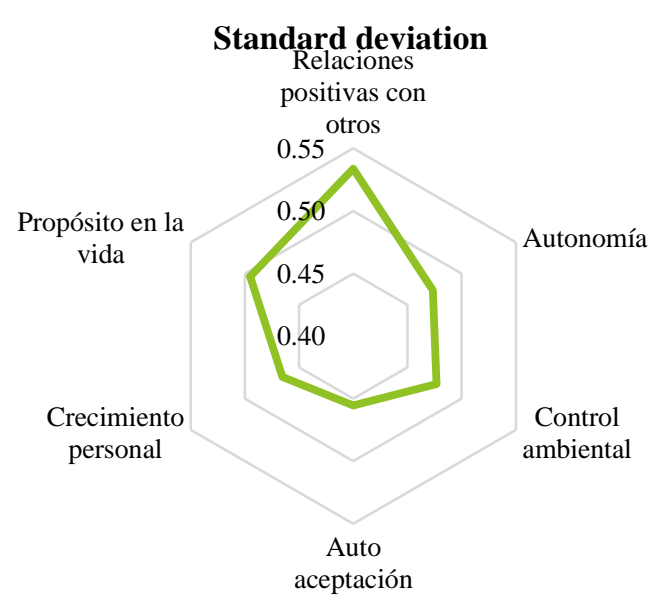

Graphic 4 Critical variables of well-being Source: (Own elaboration)

If we draw a comparison between the seller's orientation and the welfare variables, the following Table remains.

\begin{tabular}{|l|l|}
\hline \multicolumn{2}{|c|}{ Seller orientation } \\
\hline $\begin{array}{l}\text { To satisfy your own } \\
\text { problems }\end{array}$ & Purpose in life \\
\hline Towards the competition & Personal growth \\
\hline Towards your product & Autonomy \\
\hline To bargains & Self acceptance \\
\hline Towards relationships & $\begin{array}{l}\text { Positive relationships with } \\
\text { others }\end{array}$ \\
\hline The technical vendor & Environmental control \\
\hline
\end{tabular}

Table 9 Comparison between the seller's orientation and the welfare variables

Source: (Own elaboration)

From this perspective, this sales team is recommended:

1. Improve the feeling of control and competence, improve control of activities, take advantage of opportunities, develop the ability to create or choose contexts, through:

a. Training on the sales process (specific documentation, flow charts, people involved) and followup of clients.

b. Study successful cases and cases of what is not done in the sales process.

c. Perform role-play of customer interaction to improve trust and personal relationships.

2. Mitigate feelings of helplessness, generalized external locus, feeling of lack of control, by: a. Clearly publicize work policies, as well as possible sanctions.

b. Promote assertive communication by managers to mitigate the feeling of threats.

c. Have a control board on progress of weekly and monthly goals.

3. Develop close and warm relationships with others, care for the well-being of others (particularly the well-being of the organization), capacity for strong empathy, affection and intimacy.

a. Implement a code of ethics, which establishes guidelines for conduct and respect.

b. Promote policies of decent labor treatment in which time roles and permits are considered in common agreement with the management levels based on personal needs and fulfillment of goals.

4. Mitigate the deficient sensation of affection, intimacy and empathy.

a. Regularly carry out transparency practices in personal relationships.

b. Schedule monthly meetings for personal coexistence.

c. Schedule family day once a quarter, in which family members can get to know the workspace.

Although this research presents the result of the automotive commercial area, the MORACH reveals very valuable information for improving performance, and can be applied to other areas of the organization. 
Although there are instruments to determine psychological profiles of people, by means of the radial graph of the standard deviation it is possible to appreciate where the data with greater dispersion are found, so it is necessary to work proportionally in each of the variables, what how was presented in Graphic 4, the main variables in which it is necessary to improve performance is in positive relationships with others, that is to say, adhere to a code of conduct and promote it from senior management, as well as improve the feeling of environmental control.

On the other hand, the profile of the seller that is proposed as having the greatest possibility of success is the technical seller, taking care to maintain an optimal performance in the rest of the variables evaluated.

So, the seller is expected to: is busy guiding, advising and serving, knowing the problems and motivations of the prospect and establishing positive relationships, takes care of knowing your product well, talks about the benefits and knows how to adapt the qualities to the prospect, uses a technical and persuasive process to demonstrate what the product or service can do for him. Master administrative procedures and establish positive relationships with superiors and teammates. It complies with rules and regulations in a framework of transparency and honesty, where active listening is a learning factor. It is proposed that the following evaluation list be considered in the seller's profile, in which acceptable minimums of the desired profile (PD) are established and compared with the result (R), on a scale of 1 to 5 .

\begin{tabular}{|c|c|c|c|c|c|}
\hline (c) & PD & $\mathbf{R}$ & $\begin{array}{l}\text { Well-being } \\
\text { variables }\end{array}$ & PD & $\mathbf{R}$ \\
\hline $\begin{array}{l}\text { To satisfy } \\
\text { your own } \\
\text { problems }\end{array}$ & 4 & & Purpose in life & 4 & \\
\hline $\begin{array}{l}\text { Towards the } \\
\text { competition }\end{array}$ & 4 & & Personal growth & 4 & \\
\hline $\begin{array}{l}\text { Towards your } \\
\text { product }\end{array}$ & 4 & & Autonomy & 4 & \\
\hline To bargains & 4 & & Self acceptance & 4 & \\
\hline $\begin{array}{l}\text { Towards } \\
\text { relationships }\end{array}$ & 4 & & \begin{tabular}{|l|} 
Positive \\
relationships \\
with others \\
\end{tabular} & 4 & \\
\hline $\begin{array}{l}\text { The technical } \\
\text { vendor }\end{array}$ & 4 & & $\begin{array}{l}\text { Environmental } \\
\text { control }\end{array}$ & 4 & \\
\hline
\end{tabular}

Table 10 Evaluation of the seller's profile

\section{Acknowledgments}

To the Technological University of Valle de Toluca for sponsoring this research.

\section{Conclusions}

The automotive industry in its commercial segment should consider new alternatives for the evaluation and development of its personnel, because even though the results are measured by sales indicators, they could achieve better results by enhancing the skills of salespeople and mitigating those that affect Its performance.

Although salespeople tend to be individualistic due to the natural tendency to win more sales, it is important that they develop socio-emotional skills such as positive relationships with others for better organizational well-being, interaction with agency staff and of course, developing better relationships. with potential buyers and clients.

The analysis of the variables makes it possible to identify the strengths and weaknesses of each salesperson, as well as of the work team, providing very useful information to sales managers.

It is necessary to direct the efforts of sales management to develop work teams with soft skills such as positive relationships and environmental control, with this it can considerably improve productivity and work environment, considering that economic conditions are an independent variable, even in times of adversity achieve the best results.

\section{References}

AMIA. (30 de enero de 2018). Retrieved July 30, 2019, de Diálogo con la industria Automotriz: http://www.amia.com.mx/boletin/dlg20182024. pdf

cursando.com. (Sep 1, 2019). cursando.com. Obtained from https://cursando.cl/blog/habilidades-blandas/

González, L. (July 16, 2019). El Economista. Obtenido de https://www. eleconomista.com.mx 
González, L. (September 7, 2020). El Economista. Obtenido de Industria automotriz perdió cerca de 62,000 empleos en el primer semestre de 2020: https://www.eleconomista.com.mx/empresas/In dustria-automotriz-perdio-cerca-de-62000empleos-en-el-primer-semestre-de-202020200907-0057.html

Hervás, G. (2009). Psicología positiva:una introducción. Revista interuniversitariade formación del profesorado, 34-35.

INEGI. (December 12, 2018). INEGI. Recuperado el 30 de julio de 2019, de https://www.inegi.org.mx/contenidos/saladepre nsa/boletines/2018/OtrTemEcon/CndoIndAuto. pdf

INFOAB. (August 7, 2020). INFOAB. Obtenido de La industria automotriz se recupera, pero estima una caída anual del $30 \%$ : https://www.infobae.com/america/mexico/2020 /08/07/la-industria-automotriz-se-recuperapero-estima-una-caida-anual-del-30/

Ingram, T., LaForge, R., Ávila, R., \& Schwepcker, C. (2016). Perspectiva General de la venta personal. En T. Ingram, R. LaForge, R. Ávila, \& C. Schwepcker, Vtas (págs. 3-30). México: CENGAGE.

Llamas, J. M. (2009). La psicodinamia del vendedor. En J. M. Llamas, Estructura científica de la venta (págs. 393-402). México: Limusa.

Martínez, A. (September 7, 2020). La Razón. Obtenido de AMDA prevé caída de $28 \%$ en venta de autos al cierre de 2020: https://www.razon.com.mx/negocios/amda-inamejoran-perspectivas-crecimiento-industriaautomotriz-ano-404459

Olvera, E. (2016). Análisis de la evaluación del desempeño. Lerma, México: UTVT.

Olvera, E., Pedroni, F., \& Pérez, J. (2017). Modelo Organizacional de Retroalimentación para el Aprendizaje del Capital Humano: MORACH. Revista de Sistemas y Gestion Educativa, 1-13.
Sandoval, A. (July 24, 2019). altonivel. Obtenido de ¿México necesita más crecimiento o más desarrollo?: https://www.altonivel.com.mx/economia/mexic o-necesita-mas-crecimiento-o-mas-desarrollo/

Sandoval, A. (07/15/2019). Analistas creen economía no acera en recesión por ahora. Obtenido de https://www.altonivel.com.mx/economia/analist as-creen-economia-no-caera-recesion-porahora/ 